Volume I Tahun 2021

November 2021
E-ISSN: 2808-5361

http://e-journal.fkmumj.ac.id/
Proceeding The First

Muhammadiyah

Internasional- Public Health

and Medicine Conference

\title{
Non-Pharmacological Interventions for Anemia Treatment: Systematic Review
}

\author{
${ }^{1}$ Sitti Zakiyyah Putri, ${ }^{2}$ Budu, ${ }^{3}$ Gemini Alam, ${ }^{4}$ Rosdiana Natsir \\ ${ }^{1}$ Doctoral Study Program of Medical Sciences, Hasanuddin University, \\ ${ }^{2}$ Faculty of Medicine, Hasanuddin University, \\ ${ }^{3}$ Faculty of Pharmacy, Hasanuddin University, \\ ${ }^{4}$ Hasanuddin University Faculty of Medicine \\ ${ }^{1,2,3,4} \mathrm{Jl}$. Pioneer of Independence Km. 10 Makassar \\ Email: zakiyyahputri1807@gmail.com
}

\begin{abstract}
The global prevalence of anemia in non-pregnant women, of childbearing age, is estimated at $29.0 \%$ and is more common in low-and middle-income countries, women belonging to low socioeconomic strata. iron deficiency can cause direct or risky disability. To determine the effectiveness of NonPharmacological Interventions for the treatment of anemia. The method used is with the help of electronic databases from journals that have been published through PubMed, Proquest, EBSCOhost, and Science Direct as many as 6 articles were reviewed from 1186 articles. The 6 articles reviewed in this study with varied respondents using patients, male rats, nurses, Sprague-Dawley (SD) Rattus norvegicus Domestica, bovine serum, premature neonates. Non-pharmacological interventions developed in the treatment of anemia in both human and animal samples as well as the development of treatment and laboratory examinations in the treatment of anemia are Nursing Delirium Screening scale, Hepcidin expression, pain identification, HM10760A, Divalent metal transporter DMT1/SLC11A2, conservative management
\end{abstract}

Keywords: Intervention, Non-pharmacological, Anemia 


\section{INTRODUCTION}

The global prevalence of anemia in non-pregnant women, of childbearing age, is estimated at $29.0 \%$ (WHO, 2012), and is more common in low- and middle-income countries or women belonging to low socioeconomic strata ((Zhu et al., 2021). Anemia has multiple direct causes that always coexist: can be caused by infectious parasites (Kumar et al., 2020) inflammatory disorders (De-Regil et al., 2015) congenital abnormalities of hemoglobin structure; oxidative stress (i.e. imbalance between free radicals and antioxidants) ) and deficiencies of vitamins and minerals such as vitamins A and B12, and folate, and especially iron, which account for half of the anemia cases (Who and Chan, 2011).

Iron deficiency from the long-term imbalance caused by inadequate iron intake, poor absorption or utilization of iron, increased iron requirements, or chronic blood loss (Alleyne, Horne, and Miller, 2008). Individual iron requirements vary widely across the human life cycle ((2017), 2017), and are both physiological (eg, pregnancy or early postpartum) or pathological (eg, HIV infection) conditions that affect iron requirements (Who and Chan, 2011). Postmenarchal women are at a higher risk of developing iron deficiency due to missed periods, and if iron intake is insufficient, this condition can develop into anemia (known as iron deficiency anemia or IDA).

Iron deficiency is one of the most common forms of malnutrition globally. It is estimated that $50 \%$ of anemia is caused by iron deficiency worldwide (WHO, 2012). Iron deficiency, can cause disability directly or is a risk factor for it (Helmyati et al., 2018). For example, it causes impaired muscle function and impaired resistance to infection in all age groups (Solehati, Sriati, and Kosasih, 2020), and is associated with decreased physical capacity and work performance in adolescents and adults (WHO, 2012). Most women worldwide enter pregnancy with less than the desired iron stores, which reduces their reproductive performance (Zhu et al., 2021). In addition to iron deficiency, women often lack other vitamins and minerals that play an important role in the body (Tam et al., 2020). Adequate intake of folate during the periconceptional period, for example, is very important in reducing the risk of giving birth to a baby with defects. (De-Regil et al., 2015) Vitamin B12 and folate deficiencies are the main causes of anemia (Zhu et al., 2021), whereas vitamin B12 and folate deficiency are the main causes of anemia (Zhu et al., 2021), while vitamin B12 A regulates many critical functions, including vision, the integrity of epithelial tissue (e.g. membrane tissue covering internal organs and other internal body surfaces), expression of several hundred genes, and their deficiency also contributes to nutritional anemia (D'Adamo et al., 2018). ). Although this deficiency may not translate into a comparable prevalence of anemia, supplementation of this nutrient in women may improve their health throughout life, as there are some indications that this deficiency is a public health concern in certain countries (Brito et al., 2015) 
Anemia in women of childbearing age is diagnosed when the hemoglobin concentration in the blood is below $120 \mathrm{~g} / \mathrm{L}$, an example that varies with residence, altitude above sea level (altitude), and smoking (Wegmüller et al., 2020). Iron deficiency anemia is diagnosed by the combined presence of anemia and iron deficiency, measured by ferritin $(<15 \mathrm{Og} / \mathrm{L})$ or other indicators of iron status such as serum transferrin receptor or zinc protoporphyrin (Wegmüller et al., 2020).

Efforts to treat anemia can be done with pharmacological or non-pharmacological therapy. Pharmacologically, this can be done by consuming drugs including iron supplements, vitamin B12, folic acid, and blood transfusions can be done. It can also be done with non-pharmacological therapies such as consuming fruits, dates, vegetables, rosella tea, and also Moringa leaf extract. All of these ingredients can be made into juices, puddings, or in the form of tea brews that can be interesting to consume. (A Vriori Reysca Avista, Prabowo and Hafiduddin, 2019)

Many studies have been carried out to overcome anemia, both in young women and WUS, and indeed the condition of anemia must be resolved immediately considering the dangerous effects if anemia is just ignored, this situation is a factor in compiling a systematic review related to nonpharmacological therapy used to improve anemia (Official and Fibrinika Tuta Setiani, 2020)

Acetylcholinesterase and butyrylcholinesterase in cardio surgical patients with postoperative delirium. Further studies with patients in cardiac surgery are needed to evaluate the possible combination of delirium and the cholinergic transmitter system. 217 patients were included in a randomized controlled trial that tested non-pharmacological modification of care in cardiac, surgical ICU to reduce delirium.

Pentosan polysulfate to control hepcidin expression in vitro and in vivo, PPS compounds have been approved for use in humans and therefore several steps of clinical trials have been carried out and it could be advantageous in terms of time and cost savings for approval of PPS to control hepcidin in vivo.

The pain of children with sickle cell disease: nursing approach, Several strategies used to improve the comfort of children in hospital, trying to provide some solutions during the crisis: providing a comfortable and calm environment for them, encouraging them to hydrate and rest in bed, address pain triggers and stimulate walking if possible

Toxicity of single and repeated doses of HM10760A, long-acting erythropoietin, in rats and monkeys, confirmation can be made of the expected pharmacological effect of HM10760A, namely increased erythropoiesis. In the primary 13-week repeated toxicity study, treatment with HM10760A led to increased erythropoiesis in all testites of the treated group with a documented increase in erythrocyte count. 
Discovery and characterization of a novel uncompetitive inhibitor of the divalent metal transporter DMT1/SLC11A2 DMT1 Iron uptake. A new compound, pyrimidine 8, was discovered which mediates a reversible linear noncompetitive inhibition of the hDMT1 transporting activity. experimental evidence that hDMT1 can be allosterically regulated by pharmacological agents.

Non-pharmacological management of the hemodynamically significant patent ductus arteriosus, a broad range of strategies used including universal or targeted prophylaxis, medical and surgical strategies to close a PDA that may be early or late, and finally a conservative approach to a PDA shunt. Trials are ongoing progress to investigate the impact of a conservative approach and investigate the effect of initial targeted therapy based on the PDA risk score. In the meantime, clinicians should use the best available evidence to guide treatment approaches.

The purpose of this systematic review is to determine the effectiveness of nonpharmacological interventions in the treatment of anemia.

\section{METHODS}

The process in published journal articles in this systematic review refers to PRISMA for all stages of the review, searching using 4 electronic databases namely Pubmed, Proquest, EBSCOhost, and Science Direct using keywords in English "nurse* AND nonpharmacologic therapy OR nonpharmacological AND anemia" is the main search keyword that yielded 1186 articles. Journals are then specified based on the inclusion criteria, namely 1). Articles published in full text and English 2). Articles published in the last 10 years $(2011$ - 2021) 3). full articles 4). Type of research Experiment 5). Duplicate. After being determined based on the inclusion criteria, the remaining 82 articles, then selecting the same article from the four search databases with the content "Non-Pharmacological and Anemia" and determined based on the inclusion criteria, the remaining 12 articles. Then it is selected again based on the purpose into 6 articles and will be reviewed, which can be seen in Figure.1

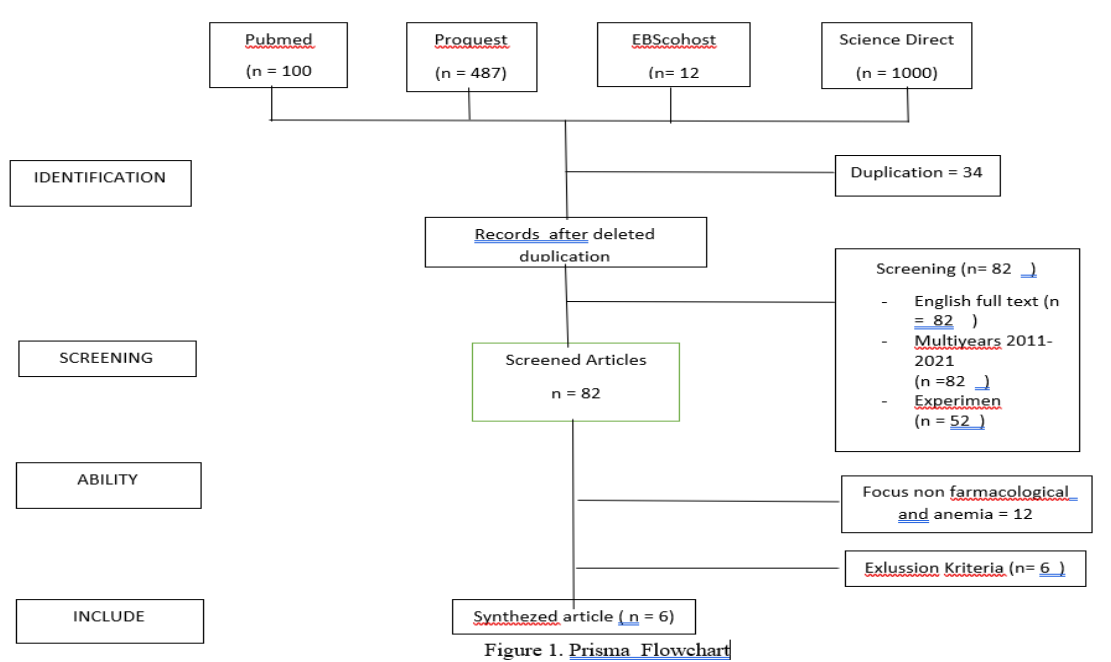


Volume I Tahun 2021 November 2021
E-ISSN: 2808-5361

http://e-journal.fkmumj.ac.id/
Proceeding The First

Muhammadiyah

Internasional- Public Health and Medicine Conference

Tabel.1 Journal Articles Review

\begin{tabular}{|c|c|c|c|c|c|c|c|c|c|}
\hline No. & Writer & Design & Country & Aim & Component & Respondent & Follow Up & Title & Results \\
\hline 1. & $\begin{array}{l}\text { John et, } \\
\text { al }\end{array}$ & $\begin{array}{l}\text { Nursing } \\
\text { Delirium } \\
\text { Screening } \\
\text { Scale } 2 \\
\text { times a day } \\
\text { for the first } 3 \\
\text { days after } \\
\text { surgery }\end{array}$ & Germany & $\begin{array}{l}\text { Assessing } \\
\text { AChE and } \\
\text { BChE in } \\
\text { patients after } \\
\text { cardiac } \\
\text { surgery and } \\
\text { the association } \\
\text { with } \\
\text { postoperative } \\
\text { delirium }\end{array}$ & $\begin{array}{l}\text { Preoperative } \\
\text { variables, } \\
\text { surgical and } \\
\text { anesthetic } \\
\text { variables, } \\
\text { postoperative } \\
\text { variables }\end{array}$ & $\begin{array}{l}217 \text { patients } \\
\text { included in a } \\
\text { randomized } \\
\text { controlled } \\
\text { trial testing } \\
\text { non- } \\
\text { pharmacolog } \\
\text { ical } \\
\text { modification } \\
\text { of care in } \\
\text { cardiac, } \\
\text { surgical ICU } \\
\text { to reduce } \\
\text { delirium }\end{array}$ & $\begin{array}{l}\text { Further studies } \\
\text { with patients } \\
\text { in cardiac } \\
\text { surgery are } \\
\text { needed to } \\
\text { evaluate the } \\
\text { possible } \\
\text { combination } \\
\text { of delirium } \\
\text { and systemic } \\
\text { cholinergic } \\
\text { transmitters }\end{array}$ & $\begin{array}{l}\text { Acetylcholinesterase } \\
\text { and } \\
\text { butyrylcholinesterase in } \\
\text { cardio surgical patients } \\
\text { with postoperative } \\
\text { delirium }\end{array}$ & $\begin{array}{l}\text { Of the } 217 \text { patients } \\
60(27.6 \%) \\
\text { developed } \\
\text { postoperative } \\
\text { delirium (POD), } \\
\text { patients with older } \\
\text { POD }(\mathrm{p}=0.005) \text { had } \\
\text { anemia }(\mathrm{p}=0.01) \text { and } \\
\text { worsened renal } \\
\text { function }(\mathrm{p}=0.006)\end{array}$ \\
\hline 2. & $\begin{array}{l}\text { Asperti } \\
\text { et, al }\end{array}$ & $\begin{array}{l}\text { Experimenta } \\
1 \\
\text { - Cell culture } \\
\text { and } \\
\text { chemical } \\
\text { treatment } \\
\text { - } \\
\text { Quantitative } \\
\text { QRT-PCR } \\
\text { - } \\
\text { Immunoblot } \\
\text { s } \\
\text { - Mouse } \\
\text { - } \\
\text { Determinatio } \\
\text { n of serum } \\
\text { hepcidin by } \\
\text { mass }\end{array}$ & Italy & $\begin{array}{l}\text { aimed to } \\
\text { verify whether } \\
\text { PPS has anti- } \\
\text { hepcidin } \\
\text { activity in } \\
\text { hepatoma cell } \\
\text { lines and mice. } \\
\text { Our results } \\
\text { show that PPS } \\
\text { strongly and } \\
\text { rapidly } \\
\text { inhibits the } \\
\text { expression of } \\
\text { hepcidin } \\
\text { which } \\
\text { suppresses } \\
\text { BMP/ } \\
\text { SMAD }\end{array}$ & $\begin{array}{l}\text { PPS inhibits } \\
\text { hepcidin } \\
\text { expression in } \\
\text { HepG2. cells } \\
\text { - PPS inhibits } \\
\text { hepcidin } \\
\text { expression in } \\
\text { HepG2 cells } \\
\text { after } 3 \text { h } \\
\text { - PPS } \\
\text { decreases } \\
\text { hepcidin } \\
\text { induction by } \\
\text { inflammatory } \\
\text { stimuli on } \\
\text { HepG2. cells } \\
\text { - PPS reduces } \\
\text { hepcidin in }\end{array}$ & $\begin{array}{l}\text { C57BL/J6 } \\
\text { male mice } \\
\text { (Harlan } \\
\text { Laboratories } \\
\text { ) were } \\
\text { maintained } \\
\text { in the } \\
\text { standard } \\
\text { diet for up to } \\
8 \text { or } 9 \\
\text { weeks. The } \\
\text { study was } \\
\text { approved by } \\
\text { the Institute } \\
\text { Committee } \\
\text { on Animal } \\
\text { Care and } \\
\text { Use of the }\end{array}$ & $\begin{array}{l}\text { PPS } \\
\text { compounds } \\
\text { have been } \\
\text { approved for } \\
\text { use in humans } \\
\text { and therefore } \\
\text { several steps } \\
\text { of clinical } \\
\text { trials have } \\
\text { been carried } \\
\text { out and it } \\
\text { could be } \\
\text { advantageous } \\
\text { in terms of } \\
\text { time and cost } \\
\text { savings for } \\
\text { approval } \\
\text { PPS to control }\end{array}$ & $\begin{array}{l}\text { Pentosan polysulfate to } \\
\text { control hepcidin } \\
\text { expression in vitro and } \\
\text { in vivo }\end{array}$ & $\begin{array}{l}\text { show the possibility } \\
\text { to use } \\
\text { PPS as an efficient } \\
\text { anti-hepcidin } \\
\text { molecule, with } \\
\text { marginal side effects }\end{array}$ \\
\hline
\end{tabular}




\begin{tabular}{|c|c|c|c|c|c|c|c|c|c|}
\hline & & $\begin{array}{l}\text { spectrometry } \\
\text { - Statistics }\end{array}$ & & $\begin{array}{l}\text { pathways both } \\
\text { in vitro and in } \\
\text { vivo in which } \\
\text { we observed } \\
\text { also a } \\
\text { the consequent } \\
\text { effect on } \\
\text { systemic iron } \\
\text { distribution, } \\
\text { without } \\
\text { causing } \\
\text { evidence } \\
\text { side effects. }\end{array}$ & $\begin{array}{l}\text { mice after } 3 \\
\text { hours } \\
\text { - PPS readily } \\
\text { decreases } \\
\text { hepatic } \\
\text { hepcidin } \\
\text { expression in } \\
\text { a dose- } \\
\text { dependent } \\
\text { manner } \\
\text { in vivo } \\
\text { method } \\
\text { - PPS in } \\
\text { chemically } \\
\text { induced } \\
\text { inflammation } \\
\text { - Oral PPS } \\
\text { treatment }\end{array}$ & $\begin{array}{l}\text { University of } \\
\text { Brescia, } \\
\text { Italy. Four } \\
\text { or five mice } \\
\text { per } \\
\text { experimental } \\
\text { group are } \\
\text { used for } \\
\text { each type of } \\
\text { experiment } \\
\text { done. }\end{array}$ & $\begin{array}{l}\text { hepcidin in } \\
\text { vivo. }\end{array}$ & & \\
\hline 3. & $\begin{array}{l}\text { Campel } \\
\text { o I et, } \\
\text { al }\end{array}$ & $\begin{array}{l}\text { qualitative, } \\
\text { descriptive } \\
\text { and } \\
\text { exploratory } \\
\text { research, } \\
\text { conducted } \\
\text { through } \\
\text { semi- } \\
\text { structured } \\
\text { interviews } \\
\text { with } 13 \\
\text { nurses. } \\
\text { Interviews } \\
\text { were } \\
\text { transcribed } \\
\text { and after this }\end{array}$ & Brazil. & $\begin{array}{l}\text { describe how } \\
\text { nurses identify } \\
\text { pain in } \\
\text { children with } \\
\text { sickle cell } \\
\text { disease (SCD) } \\
\text { and list the } \\
\text { strategies used } \\
\text { by them in the } \\
\text { evaluation and } \\
\text { control of } \\
\text { pain. }\end{array}$ & $\begin{array}{l}\text { Characterizati } \\
\text { on of nurses } \\
\text { participating } \\
\text { in the study } \\
\text { - } \\
\text { Identification } \\
\text { of pain in } \\
\text { children with } \\
\text { sickle cell } \\
\text { disease } \\
\text { by } \\
\text { nurse } \\
\text {-Strategies for } \\
\text { evaluating and } \\
\text { controlling } \\
\text { pain in }\end{array}$ & $\begin{array}{l}\text { The } \\
\text { participants } \\
\text { were } 13 \\
\text { nurses (part- } \\
\text { time and } \\
\text { full-time } \\
\text { nurses). } \\
\text { selected by } \\
\text { random } \\
\text { probability } \\
\text { sampling - } \\
\text { where all } \\
\text { elements } \\
\text { from the } \\
\text { population } \\
\text { has the same }\end{array}$ & $\begin{array}{l}\text { Several } \\
\text { strategies are } \\
\text { used to } \\
\text { increase the } \\
\text { comfort of } \\
\text { children in the } \\
\text { hospital, } \\
\text { trying to } \\
\text { provide } \\
\text { several } \\
\text { solutions } \\
\text { during the } \\
\text { crisis: } \\
\text { I provide them } \\
\text { with a } \\
\text { comfortable }\end{array}$ & $\begin{array}{l}\text { The pain of children } \\
\text { with sickle cell disease: } \\
\text { a nursing approach }\end{array}$ & $\begin{array}{l}\text { This study shows } \\
\text { that nurses can } \\
\text { identify pain in } \\
\text { children by } \\
\text { SCD from the } \\
\text { signals they emit, } \\
\text { such as constant } \\
\text { crying, restlessness, } \\
\text { facial expressions, } \\
\text { and verbal reports. } \\
\text { Pain is hard } \\
\text { evaluation due to a } \\
\text { lack of instruments, } \\
\text { such as pain scales. } \\
\text { To control their pain } \\
\text { they use emotional }\end{array}$ \\
\hline
\end{tabular}


Volume I Tahun 2021 November 2021
E-ISSN: 2808-5361 http://e-journal.fkmumj.ac.id/
Proceeding The First

Muhammadiyah

Internasional- Public Health and Medicine Conference

\begin{tabular}{|c|c|c|c|c|c|c|c|c|c|}
\hline & & $\begin{array}{l}\text { process } \\
\text { qualitative } \\
\text { data } \\
\text { organized } \\
\text { according to } \\
\text { thematic } \\
\text { analysis. }\end{array}$ & & & $\begin{array}{l}\text { children } \\
\text { with sickle } \\
\text { cell disease } \\
\text {-The impact } \\
\text { of "pain and } \\
\text { hospitalization } \\
\text { " on daily life } \\
\text { children with } \\
\text { sickle cell } \\
\text { disease } \\
\text { - }\end{array}$ & $\begin{array}{l}\text { probability } \\
\text { of being } \\
\text { selected as a } \\
\text { sample } \\
\text { elements -, } \\
\text { through } \\
\text { monthly } \\
\text { scale } \\
\text { drawings } \\
\text { from } \\
\text { inpatient } \\
\text { sector. We } \\
\text { included } \\
\text { nurses who } \\
\text { worked for } \\
\text { at least one } \\
\text { year } \\
\text { and } \\
\text { regardless of } \\
\text { gender and } \\
\text { choose these } \\
\text { criteria } \\
\text { because they } \\
\text { are } \\
\text { professional } \\
\text { will be } \\
\text { more used } \\
\text { for } \\
\text { child } \\
\text { care, } \\
\text { own } \\
\text { more } \\
\text { knowledge }\end{array}$ & $\begin{array}{l}\text { and calm } \\
\text { environment, } \\
\text { encourage } \\
\text { them to } \\
\text { hydrate and } \\
\text { rest in bed, } \\
\text { address pain } \\
\text { triggers and } \\
\text { stimulate } \\
\text { walking } \\
\text { whenever } \\
\text { possible. }\end{array}$ & & $\begin{array}{l}\text { support, comfort } \\
\text { promotion } \\
\text {, and administering } \\
\text { medication } \\
\text { prescribed by a } \\
\text { doctor }\end{array}$ \\
\hline 4 & Kyu & Preclinical & The & to assess acute & HM10760A. & Sprague- & confirmation & Single and repeated & Based on a 13-week \\
\hline
\end{tabular}


Volume I Tahun 2021 November 2021
E-ISSN: 2808-5361 http://e-journal.fkmumj.ac.id/
Proceeding The First

Muhammadiyah

Internasional- Public Health and Medicine Conference

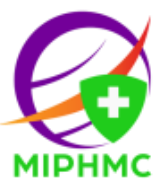

MIPHMC

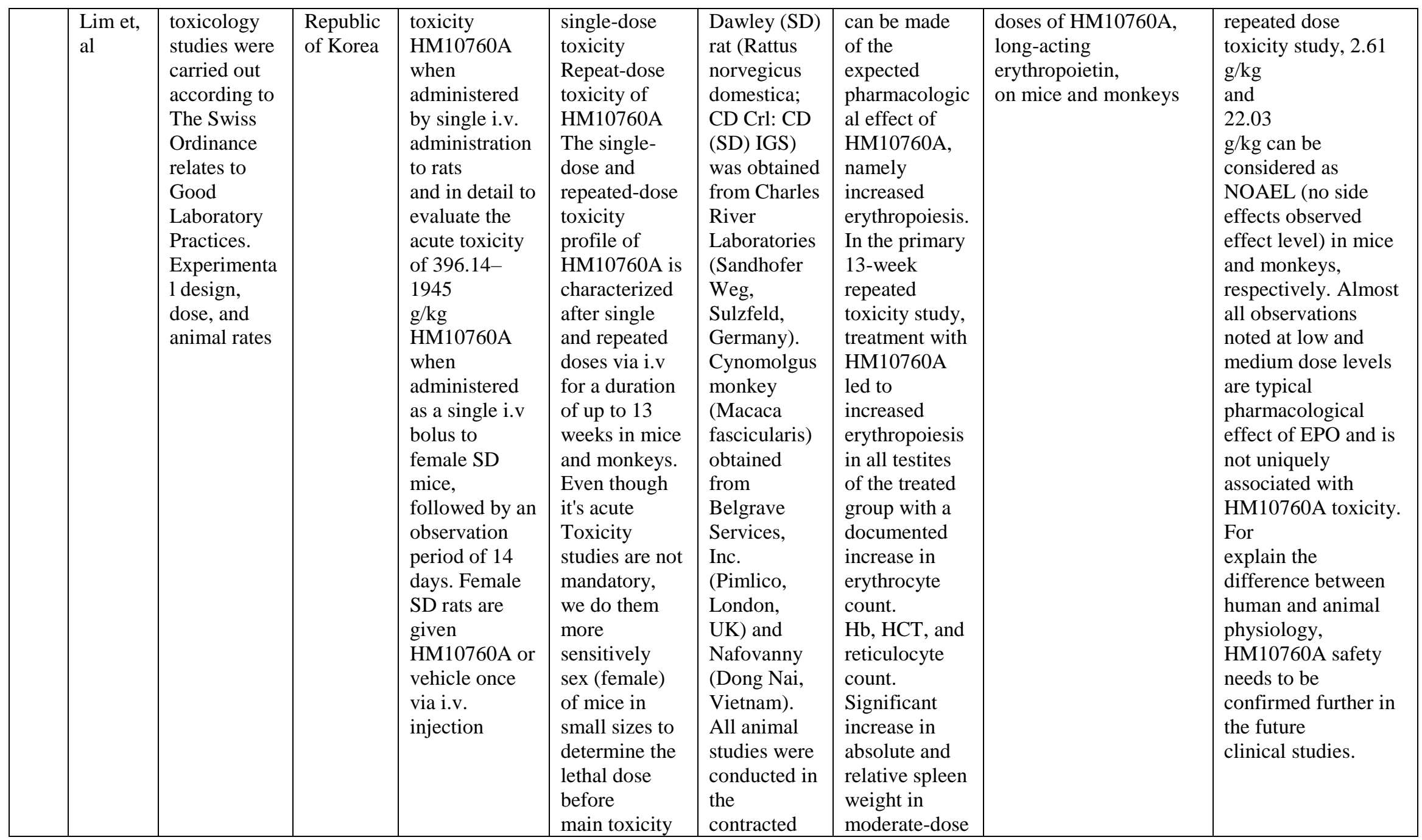


Volume I Tahun 2021 November 2021
E-ISSN: 2808-5361 http://e-journal.fkmumj.ac.id/
Proceeding The First

Muhammadiyah

Internasional- Public Health and Medicine Conference

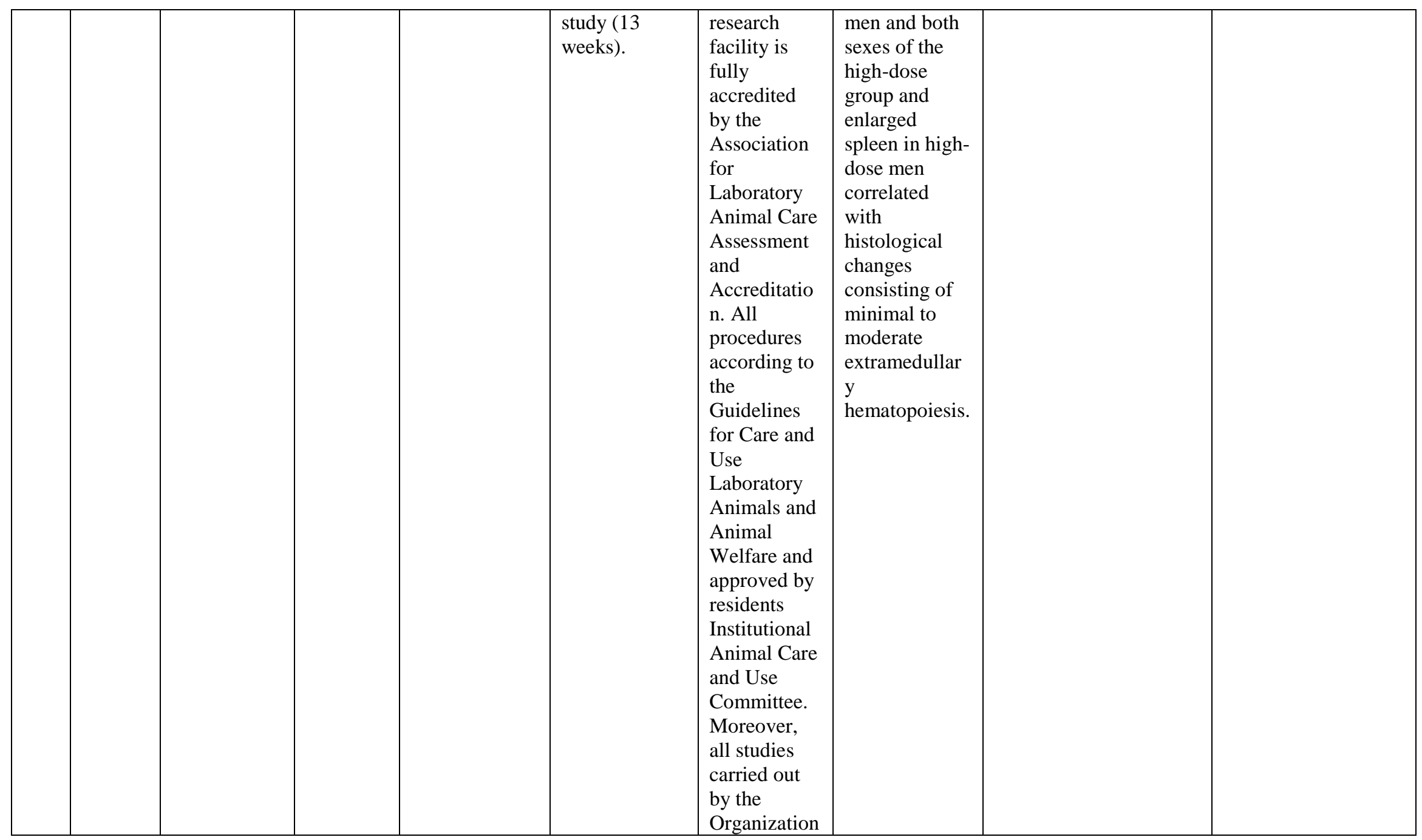




\begin{tabular}{|c|c|c|c|c|c|c|c|c|c|}
\hline & & & & & & $\begin{array}{l}\text { for } \\
\text { Economic } \\
\text { Co- } \\
\text { Operations } \\
\text { and } \\
\text { Developmen } \\
\text { t (OECD): } \\
\text { Principles of } \\
\text { Good } \\
\text { Laboratories } \\
\text { Practice, } \\
\text { ENV / MC / } \\
\text { CHEM (98) } \\
17 .\end{array}$ & & & \\
\hline 5. & $\begin{array}{l}\text { Montal } \\
\text { betti et, } \\
\text { al }\end{array}$ & $\begin{array}{l}\text { HEK293 cell } \\
\text { It was } \\
\text { obtained } \\
\text { From } \\
\text { America } \\
\text { Type } \\
\text { Culture } \\
\text { Collection } \\
\text { (ATCC). } \\
\text { Lipofectami } \\
\text { ne 2000 } \\
\text { And genetics } \\
\text { It was } \\
\text { obtained } \\
\text { from } \\
\text { Life } \\
\text { Technology } \\
\text { (Basel, } \\
\text { Switzerland) } \\
\text {. }\end{array}$ & $\begin{array}{l}\text { Switzerla } \\
\text { nd. }\end{array}$ & $\begin{array}{l}\text { Divalent } \\
\text { metal } \\
\text { transporter-1 } \\
\text { (SLC11A2/D } \\
\text { MT1) } \\
\text { utility } \\
\text { that } \\
\text { H } \\
\text { electrochemist } \\
\text { ry } \\
\text { gradient } \\
\text { as } \\
\text { that } \\
\text { drive } \\
\text { compel } \\
\text { for } \\
\text { transport } \\
\text { divalent } \\
\text { metal } \\
\text { ion }\end{array}$ & $\begin{array}{l}\text { Compound } \\
\text { filtering } \\
\text { for DMT1 } \\
\text { Inhibitor } \\
\text {-It is not } \\
\text { competitive } \\
\text { Inhibition of } \\
\text { hDMT1 by } \\
\text { pyrimidine } 8 \\
\text { - } \\
\text { Determination } \\
\text { From } \\
\text { pyrimidine } 8 \\
\text { inhibition } \\
\text { constant } \\
\text { in } \\
\text { DMT1 Fe } 2+\text {. } \\
\text { mediated } \\
\text { Absorption } \\
\text {-Pyrimidine }\end{array}$ & Beef serum & $\begin{array}{l}\text { DMT1 } \\
\text { Absorption } \\
\text { iron. } \\
\text { found } \\
\text { a } \\
\text { a new } \\
\text { compound, } \\
\text { pyrimidine 8, } \\
\text { which } \\
\text { mediate } \\
\text { a } \\
\text { reversible } \\
\text { linear } \\
\text { uncompetitive } \\
\text { inhibition } \\
\text { from } \\
\text { hdmt1 } \\
\text { transport } \\
\text { activity. }\end{array}$ & $\begin{array}{l}\text { Discovery and } \\
\text { Characterization of } \\
\text { A novel } \\
\text { it is not competitive } \\
\text { inhibitor of } \\
\text { it is divalent } \\
\text { metal transporter } \\
\text { DMT1 / SLC11A2 }\end{array}$ & $\begin{array}{l}\text { Breakthrough } \\
\text { discovery } \\
\text { in pharmacy, } \\
\text { how } \\
\text { this transporter } \\
\text { work and } \\
\text { how } \\
\text { can be modulated. } \\
\text { Becomes } \\
\text { pharmacologically } \\
\text { Which may } \\
\text { for } \\
\text { structure-based } \\
\text { drug design. }\end{array}$ \\
\hline
\end{tabular}


Volume I Tahun 2021 November 2021
E-ISSN: 2808-5361 http://e-journal.fkmumj.ac.id/
Proceeding The First

Muhammadiyah

Internasional- Public Health and Medicine Conference

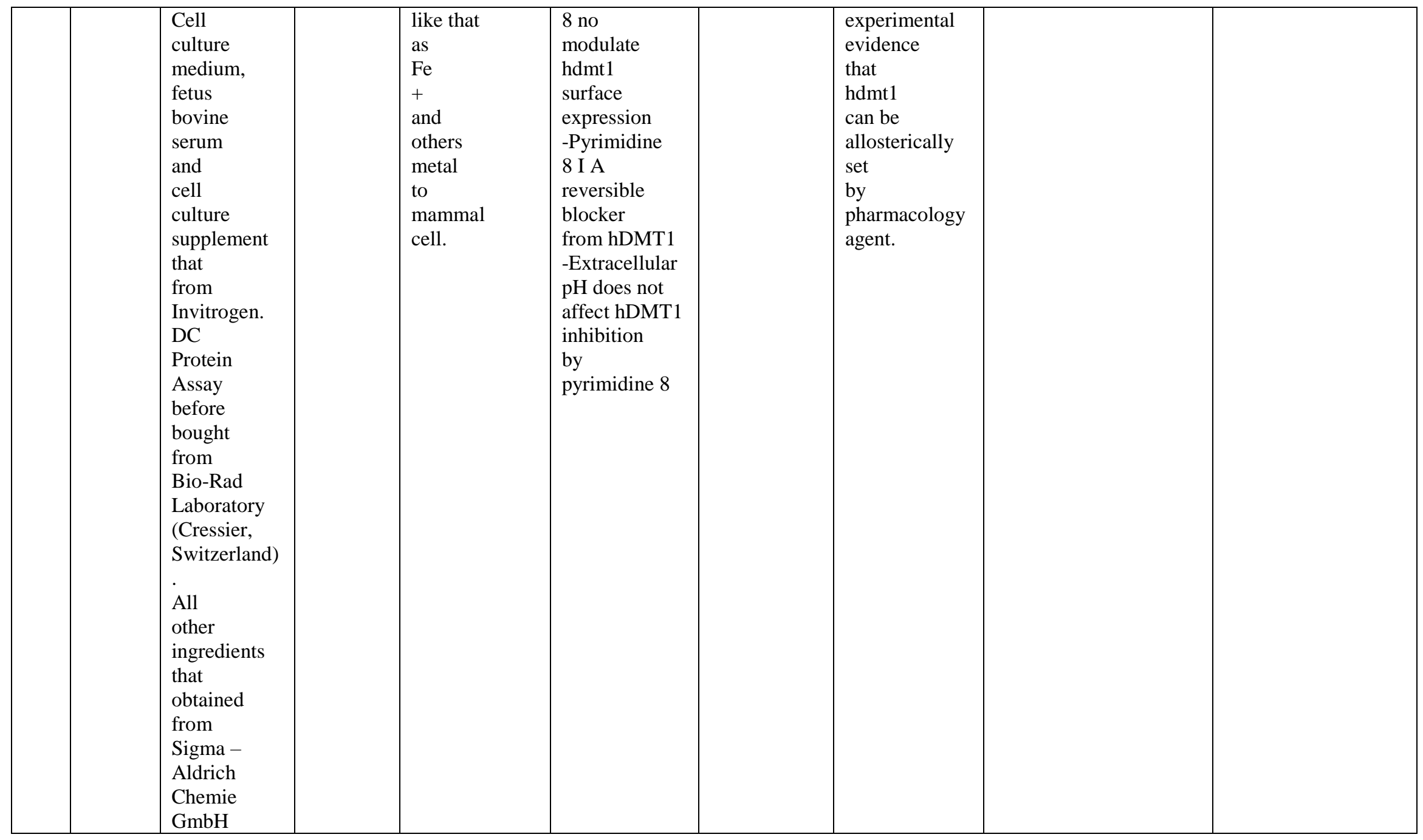




\begin{tabular}{|c|c|c|c|c|c|c|c|c|c|}
\hline & & $\begin{array}{l}\text { (Buchs, } \\
\text { Switzerland) }\end{array}$ & & & & & & & \\
\hline 6. & $\begin{array}{l}\text { Smith } \\
\text { et, al }\end{array}$ & $\begin{array}{l}\text { management } \\
\text { of premature } \\
\text { neonates } \\
\text { with PDA } \\
\text { remains } \\
\text { contentious. } \\
\text { The } \\
\text { justification } \\
\text { for a } \\
\text { conservative } \\
\text { approach to } \\
\text { PDA } \\
\text { management } \\
\text { arises from a } \\
\text { large body } \\
\text { of evidence } \\
\text { that has not } \\
\text { found the } \\
\text { benefit of } \\
\text { ductal } \\
\text { closure in } \\
\text { studies of } \\
\text { prophylactic } \\
\text { treatment. } \\
\text { Conservative } \\
\text { The } \\
\text { approach } \\
\text { recommends } \\
\text { active } \\
\text { management } \\
\text { of the PDA }\end{array}$ & Ireland & $\begin{array}{l}\text { Lack of } \\
\text { Evidence } \\
\text { supporting } \\
\text { therapeutic } \\
\text { strategies } \\
\text { aimed at } \\
\text { achieving } \\
\text { PDA closure } \\
\text { has led to } \\
\text { widespread } \\
\text { adoption } \\
\text { conservative } \\
\text { management } \\
\text { aimed at } \\
\text { reducing the } \\
\text { impact of the } \\
\text { shunt volume } \\
\text { without } \\
\text { achieving } \\
\text { ductal closure }\end{array}$ & $\begin{array}{l}\text { 1. Active } \\
\text { treatment } \\
\text { approach } \\
2 \text {. } \\
\text { Conservative } \\
\text { management } \\
\text { strategy } \\
\text { - Restriction } \\
\text { of fluid intake } \\
\text { - Diuretic } \\
\text { drugs } \\
\text { - Transductal } \\
\text { flow } \\
\text { modulation } \\
\text { * PEEP and } \\
\text { inspiration } \\
\text { time } \\
\text { * } \\
\text { Hypercapnemi } \\
\text { a } \\
\text { * Oxygen } \\
\text { * Hematocrit } \\
\text { 3. Further } \\
\text { consideration }\end{array}$ & $\begin{array}{l}\text { premature } \\
\text { neonate }\end{array}$ & $\begin{array}{l}\text { widely used } \\
\text { strategies } \\
\text { include } \\
\text { universal or } \\
\text { targeted } \\
\text { prophylaxis, } \\
\text { medical and } \\
\text { surgical } \\
\text { strategies to } \\
\text { close a PDA } \\
\text { that may be } \\
\text { early or late, } \\
\text { and finally a } \\
\text { conservative } \\
\text { approach to a } \\
\text { PDA shunt. } \\
\text { Trials are } \\
\text { ongoing } \\
\text { progress to } \\
\text { investigate the } \\
\text { impact of a } \\
\text { conservative } \\
\text { approach and } \\
\text { investigate the } \\
\text { effect of initial } \\
\text { targeted } \\
\text { therapy based } \\
\text { on the PDA } \\
\text { risk score. In } \\
\text { the meantime, } \\
\text { clinicians }\end{array}$ & $\begin{array}{l}\text { Non-pharmacological } \\
\text { management of } \\
\text { hemodynamically } \\
\text { significant patents } \\
\text { ductus arteriosus }\end{array}$ & $\begin{array}{l}\text { The relationship } \\
\text { between PDA and } \\
\text { neonatal morbidity, } \\
\text { mortality, and poor } \\
\text { neurodevelopmental } \\
\text { outcomes in } \\
\text { childhood is unclear. } \\
\text { There was no } \\
\text { associated } \\
\text { improvement in } \\
\text { critical, short, and } \\
\text { long-term outcomes } \\
\text { after medical or } \\
\text { surgical PDA } \\
\text { closure. } \\
\text { - Conservative PDA } \\
\text { management } \\
\text { combines various } \\
\text { clinical strategies to } \\
\text { reduce the degree of } \\
\text { left-to-right ductal } \\
\text { shunts without } \\
\text { pursuing active PDA } \\
\text { closure by medical } \\
\text { or surgical means. } \\
\text { Research direction } \\
\text { - Conservative PDA } \\
\text { management } \\
\text { strategies require } \\
\text { systematic } \\
\text { assessment in the }\end{array}$ \\
\hline
\end{tabular}


Volume I Tahun 2021 November 2021
E-ISSN: 2808-5361 http://e-journal.fkmumj.ac.id/
Proceeding The First

Muhammadiyah

Internasional- Public Health and Medicine Conference

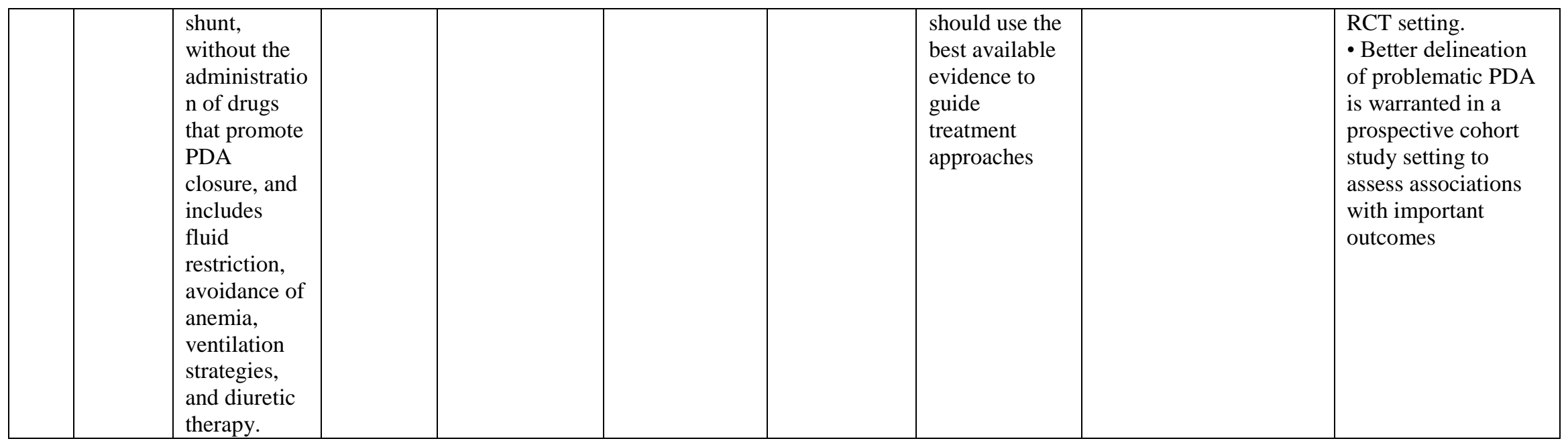




\section{RESULTS AND DISCUSSION}

The research articles reviewed were from Germany, Italy, Brazil, Korea, Ireland, Switzerland, the method used was Observation $n=1$, Experiment $n=2$, Laboratory Test $n=2$, Qualitative research $\mathrm{n}=1$. The definition of delirium according to the DSM-5 criteria includes transient and serious attentional disturbances and short-term cognition and development. Symptoms tend to fluctuate during the day and cannot be explained by preexisting neurocognitive impairment (EDA and ADS, 2014). Delirium is a symptom complex that is very common in operative and non-operative disciplines in hospitals. The incidence is very high among patients undergoing cardiac surgery (Zhai et al., 2016). The incidence in the patient population has been described to be from 30 to $80 \%$ (Zhai et al., 2016).

Nursing Delirium Screening Scale (Nu-DESC) twice daily for the first 3 days after surgery. Further outcome variables were somatic laboratory parameters and variables related to surgery, anesthesia, and postoperative recovery. 101 of venous or arterial blood was drawn and AChE and BChE were determined with the ChE check mobile from Securities. Results: Of the 217 patients, 60 (27.6\%) developed postoperative delirium (POD). Patients with POD were older $(\mathrm{p}=0.005)$, had anemia $(\mathrm{p}=0.01)$, and had worsening renal function $(\mathrm{p}=0.006)$. Subsequently, these patients had decreased intraoperative cerebral saturation (NIRS) $(\mathrm{p}<0.001)$ and higher intraoperative catecholamine requirements $(\mathrm{p}=0.03)$. Delirious patients showed more inflammatory response $(\mathrm{p}<$ 0.001). AChE and BChE values are mostly in the norm file. Patients with values outside the norm did not have POD more frequently than others. Regarding AChE and BChE patients did not differ in having delirium or not $(\mathrm{p}>0.10)$.

Hepcidin is a peptide hormone produced by the liver, with an essential role in controlling systemic iron availability. It binds to ferroportin, the only known cellular iron exporter, mediating its internalization and degradation and thereby reducing iron release (Park et al., 2001). Important to the hepcidin-ferroportin axis is the regulation of hepcidin expression, which is controlled by various factors, most of which are related to iron abundance and utilization, inflammation, hypoxia, and erythropoietic activity (Wang et al., 2017). Two main pathways are known to be responsible for hepcidin expression. An iron-mediated pathway involving the BMP/SMAD signaling pathway, in which BMP6 is a systemic iron-sensing pathway, is capable of inducing hepatic hepcidin expression. It interacts with its receptor, a complex formed by dimerization of type-II and type-I BMP receptors and the co-receptor Hemojuvelin (HJV), with subsequent phosphorylation of SMAD1/5/8, association with SMAD4, and translocation to the nucleus (Poli et al. al., 2014). The second pathway involves the inflammatory cytokine IL-6 and the JAK/STAT3 pathway (Schmidt, 2015) which cooperates with the $\mathrm{BMP} / \mathrm{SMAD}$ pathway to stimulate hepcidin expression under inflammatory conditions (Campelo et 
E-ISSN: 2808-5361 http://e-journal.fkmumj.ac.id/
Proceeding The First

Muhammadiyah

Internasional- Public Health and Medicine Conference

al., 2018). Hepcidin dysregulation is common in many pathologies related to iron imbalance. Hereditary hemochromatosis is characterized by low levels of hepcidin with consequent iron overload due to genetic mutations in iron-related genes (Brissot et al., 2018) "Refractory Iron Deficiency Anemia" (IRIDA) a genetic form of anemia, characterized by high levels of hepcidin and consequently severe iron deficiency anemia due to mutations in Tmprss6 (a serine protease acting on the HJV co-receptor as a negative controller of the BMP/SMAD pathway) (Guillem et al., 2012) and Anemia of Chronic Disease (ACD) or Anemia of inflammation (AI), a common form of anemia caused by chronic disease, infection and/or inflammation, and is characterized by high levels of hepcidin and iron deficiency (Poli et al., 2014). Due to the relevance of this disease, many groups studied different pharmacological approaches to modulate hepcidin and restore proper iron homeostasis (Ginzburg, 2019). In particular, we found that heparin is a compound that suppresses hepcidin expression induced by BMP6 and IL6, in vitro and in vivo (Poli et al., 2014). Heparin is a highly sulfated glycosaminoglycan, widely used clinically for its anticoagulant activity. Male C57BL/J6 mice (Harlan Laboratories) were maintained on a standard diet for up to 8 or 9 weeks. The study was approved by the Institutional Committee on Animal Care and Use of the University of Brescia, Italy. Four or five mice per experimental group were used for each type of experiment carried out.

a. In the first experiment, mice were treated subcutaneously (SC) with saline or PPS (single dose) and euthanized at different time points. Blood was collected for serum hepcidin and serum iron evaluation. The liver and spleen were analyzed for mRNA, protein, and/or iron content.

b. In the second experiment, mice were treated subcutaneously (SC) with saline or different doses of PPS and euthanized 6 hours after treatment.

c. In the third experiment, mice were treated intraperitoneally (IP) with LPS (1 mg/kg, to simulate acute inflammatory status) and subcutaneously (SC) with PPS. Six hours after treatment they were euthanized and analyzed as previously described.

d. In the fourth experiment, mice were treated subcutaneously (SC) or orally (by gavage) with saline or different doses of PPS to compare two different treatments. Six hours after treatment, blood was collected for serum hepcidin and serum iron evaluation, and the mice were euthanized. The liver and spleen were analyzed for mRNA, protein, and/or iron content. Spleen iron content was determined spectrophotometrically as in Roetto et al, with slight modifications [30]. Serum iron was determined spectrophotometrically with a commercial kit, according to the manufacturer's instructions (Randox Laboratories). 
E-ISSN: $2808-5361$ http://e-journal.fkmumj.ac.id/
Proceeding The First

Muhammadiyah

Internasional- Public Health and Medicine Conference

Sickle cell disease (SCD) originated in Africa and is one of the most common hereditary hematological diseases in the world (BRASIL., 2015). The predominance of this disease in Brazil is in the Northeast and Southeast regions, it is more common in the black population and their descendants (Campelo et al., 2018). In Brazil, an estimated 3,000 children are born with sickle cell disease per year; Among these children, $80 \%$ do not reach five years of age of maturity for complications of the disease and do not receive the necessary health care (Brazil and Ministério da Saúde, 2012).

$\mathrm{SCD}$ is characterized by a mutant type of hemoglobin known as hemoglobin $\mathrm{S}(\mathrm{HbS})$, which distorts erythrocytes, giving them a sickle shape (BRASIL., 2015). Disease detection is made by neonatal screening tests, seeking an early diagnosis. This allows the specialized care needed by a degenerative disease to begin (Brazil and Ministério da Saúde, 2012). Usually, the clinical picture of SCD starts at six months of age. The most common signs and symptoms are acute pain or vasoocclusive crisis, ulcers in the lower limbs, jaundice, pallor, and fatigue (BRASIL., 2015). The first vaso-occlusive crisis, also known as hand-foot syndrome, occurs in the early months of life, characterized by pain and swelling behind the hands and/or feet, sometimes accompanied by erythema and localized warmth (Neves et al., 2016). This crisis is the greatest clinical manifestation of the disease, which is caused by the blockage of small blood vessels by the sickle-shaped erythrocytes (Campelo et al., 2018). This is recognized as a sign in the patient's life, which explains the tremendous demand for emergency care and hospitalization (Campelo et al., 2018). Regarding the recognition of pain in children with SCD, some difficulties for caregivers (parents and health professionals) could be highlighted, since these children of a very young age may lack the cognitive abilities or the vocabulary to report or describe their pain (Gerardin et al., 2021). The identification of these painful events is based on each child's cognitive development. Until the age of two, the adopted valuation criteria are physiological and behavioral aspects; From this age, the reports of the children about their own experiences can be used for evaluation of the intensity or severity of the pain crisis, the use of appropriate instruments, such as pain scales is also possible (Llor, 2014). In addition to drug therapy, non-pharmacological strategies (such as emotional support and promotion of comfort) are also useful for controlling, caring for, and helping children recover. Thus, the attention paid to children with SCD during their painful experience requires skills from the nurse to recognize, evaluate and control pain, always keeping in mind the age and subjectivity of each child when dealing with their behavioral reactions, for integral and humane care. Given this discussion, we ask the question: how does a nurse identify pain in children with SCD? What are the strategies used to evaluate and control the pain? 
E-ISSN: 2808-5361 http://e-journal.fkmumj.ac.id/
Proceeding The First

Muhammadiyah

Internasional- Public Health and Medicine Conference

HM10760A is regulated by hypoxia and is a major regulator of the proliferation and maturation of erythrocyte progenitors and their direct descendants (Jelkmann and Hellwig-bürgel, 2001). Its main function is to promote red blood cell development and to initiate $\mathrm{Hb}$ production (Valent et al., 2018). It is produced in the kidney and stimulates the proliferation and differentiation of committed erythroid progenitors in the bone marrow (Lim et al., 2020) Supplementation Chronic kidney disease (CKD) are characterized by progressive kidney damage and impaired renal function (George et al., 2018) Anemia is a common complication of CKD associated with a decrease in the patient's quality of life. It causes increased morbidity and mortality and accelerates the rate of progression of CKD (George et al., 2018). In CKD patients, anemia is defined as a situation in which the concentration of hemoglobin $(\mathrm{Hb})$ in the blood is below twice the standard deviation of the average $\mathrm{Hb}$ of the general population (Izaks, Westendorp, and Knook, 1999). The hematopoietic cytokine erythropoietin (EPO) regulates the level of circulating red blood cells (RBCs), and treatment with recombinant human EPO (rhEPO) is a breakthrough in the treatment of renal anemia (Lim et al., 2020). EPO is a glycoprotein measuring about $30 \mathrm{kDa}$ with rhEPO is the standard treatment for anemia caused by end-stage renal disease and chemotherapy in cancer patients (Bohlius et al., 2006) Despite the worldwide use of rhEPO, it needs frequent administration because its short half-life has prompted the development of enhanced agent to stimulate erythropoiesis (Mahmood, 2020). Thus, the development of HM10760A with prolonged survival in circulation offers the advantages of more convenient dosing and may improve adherence and clinical effectiveness compared to authentic rhEPO.

Divalent metal transporter-1 (SLC11A2/DMT1) uses the electrochemical $\mathrm{H}$ gradient as a driving force to transport divalent metal ions such as Fe+ and other metals to mammalian cells. DMT1 is ubiquitously expressed, most notably in the proximal duodenum, immature erythroid cells, brain, and kidney. These transporters mediate $\mathrm{H} 2+2+, \mathrm{MN}$-coupled transport of ferric iron across the apical membrane of enterocytes. In addition, in cells such as those for erythroid precursors, following transferrin receptor (TfR) mediated endocytosis; it mediates the H+-coupled outflow of ferrous iron from endocytic vesicles into the cytosol. The dysfunction of human DMT1 is associated with several pathologies such as iron deficiency anemia hemochromatosis, Parkinson's disease, and Alzheimer's disease, as well as colorectal cancer and esophageal adenocarcinoma, making DMT1 an attractive target for drug discovery. Presenting the study, we performed a virtual ligand-based screening of the Princeton database (700,000 commercially available compounds) to search for pharmacophore analogs of the recently reported DMT1 inhibitor. We found a new compound, named pyrimidine 8, which mediates a reversible linear noncompetitive inhibition of human DMT1 (hDMT1) transport activity with a Ki of $+20 \mathrm{mM}$. This compound did not affect hDMT1 cell surface expression and did 
E-ISSN: 2808-5361 http://e-journal.fkmumj.ac.id/
Proceeding The First

Muhammadiyah

Internasional- Public Health and Medicine Conference

not show dependence on extracellular $\mathrm{pH}$. To our knowledge, this is the first experimental evidence that hDMT1 can be allosterically modulated by pharmacological agents. Pyrimidinone 8 represents a novel multi-purpose compound tool and it may serve as a leading structure for the development of therapeutic compounds for pre-clinical assessment. 2015ElsevierInc. All rights reserved.

Conservative PDA management combines various clinical strategies to reduce the degree of left-to-right ductal shunts without pursuing the closure of an active PDA through medical or surgical means. This is based on the premise that most PDAs eventually close spontaneously in preterm infants before discharge from the hospital. However, it is wise to recognize that a conservative approach does not mean "ignoring" the presence of a PDA, nor does it preclude active assessment and management of a PDA or permit that the known significant consequences of ductal patency in neonatal morbidity are negligible (Benitz, 2011). Echocardiographic assessment of the PDA is an integral component of the conservative approach and should be undertaken to assess the tract's impact on circulation. Once identified, this strategy aims to ameliorate the consequences of ductal shunting through fluid restriction, diuretics, modified neonatal ventilation support, permissive hypercapnia, targeting lower oxygen saturation ranges, tolerance of metabolic alkalosis, and maintaining a higher hematocrit (Campelo et al., 2018). Such a strategy aims to actively manage the consequences of high volume through increasing pulmonary vascular resistance (PVR) and/or decreasing pulmonary artery blood flow to limit left-to-right ductal shunting.

Delirium is a serious complex of various symptoms, which need to be recognized early to initiate correct and effective treatment. In the analyses, no difference in $\mathrm{AChE}$ and $\mathrm{BChE}$ in gical patients with or without postoperative delirium could be found. Further studies are needed to evaluate the possible connection between delirium and cholinergic transmitter systems. Studies investigating the pathophysiology of the cholinergic system are of great importance. Furthermore, the possible association of cardiosurgical patients in the ICU and the cholinergic transmitter system should be examined. Studies measuring acetylcholinesterase and butyrylcholinesterase in surgical patients should be assessed preoperatively and need to be continued during surgery and postoperatively (perhaps longer than three days after surgery). Not to mention the fact that the use of anticholinergic drugs must be handled with care. Further measurements should be taken more than twice a day and perhaps even at night. Because most patients after cardiac surgery develop delirium, and because of its negative impact on clinical outcomes, more studies with this patient population should be conducted in the future.

Variable Delirium n M SD p-value Summary of key findings Preoperative variables Age The focus of this analysis is the comparison of patients with and without delirium after cardiac surgery. In this patient population, the incidence of postoperative delirium was $27.6 \%$. The secondary outcome 
variables indicated that patients with moderate delirium were older, had anemia, had poorer kidney function, had lower brain saturation during surgery, and had a higher need for noradrenaline. Furthermore, these patients have a higher inflammatory response. The main outcome was that the $\mathrm{AChE}$ and $\mathrm{BChE}$ values were mainly within the norm and did not differ in patients experiencing postoperative delirium or not. Due to recent studies that considered the important role of AChE and BChE in delirious critically ill patients, this study focused on $\mathrm{AChE}$ and $\mathrm{BChE}$ in patients No after cardiac surgery and their impact on postoperative delirium. The results of this study did not show any difference in $\mathrm{AChE}$ and $\mathrm{BChE}$ in patients with delirium compared to those without.

Hepcidin is a master regulator of iron availability that controls both iron uptake from the duodenum and its release from tissue iron stores (Roth, Meynard, and Coppin, 2019). Dysregulation of hepcidin levels causes some disturbances due to iron overload if hepcidin is too low, and conversely, iron deficiency if hepcidin is too high (Zhu et al., 2021). In the first situation, the main group of disorders is hemochromatosis (types I, II, and III) and, to date, the available treatments include phlebotomy and iron chelation therapy (Brissot et al., 2018). PPS) (a semi-synthetic sulfated polysaccharide with a molecular weight of about 4000-6000 Da) appears to be a promising compound for controlling hepcidin. It is a xylose polymer and contains about two sulfate groups per carbohydrate monomer. It maintains low anticoagulant and fibrinolytic properties, 15 times less compared to heparin, and interestingly, it binds to those different heparin-binding growth factors as FGF as well as FGFR-1 receptors. It has been used in humans to treat interstitial cystitis (orally administered) and as a variety of anemias and is important for reducing thrombotic hepcidin (by oral, subcutaneous, and intravenous administration). expression restores correct hemoglobin levels and treats anemia. Among the different strategies being studied to reduce hepcidin, there is the use of heparin derivatives (Poli et al., 2014)(Poli et al., 2017) Heparin derivatives are very strong in vitro and in vivo hepcidin inhibitors and anti-hepcidin activity they involve suppression of BMP6/SMAD Based on this evidence, PPS could be a promising compound controlling hepcidin expression. To verify this hypothesis, we analyzed the effects of PPS in cells (HepG2) and in vivo as we did previously to test for heparins (Poli et al., 2017). PPS functions to suppress hepcidin expression in the HepG2 cell pathway by binding to several membrane components at low $(0.4 \mathrm{~g} / \mathrm{mL})$ and fast $(3-6 \mathrm{~h})$ concentrations, in basal, BMP6- and complexes (BMP6, receptor, co-receptor). . Interestingly, Hepcidin pentosan is stimulated by IL6/OncM. In mice, subcutaneous injection of heparin derivatives. The anti-hepcidin activity of PPS could be explained by the greater negative charge density distribution in the polysaccharide chain, which causes a high affinity for the basic groups of the protein. Interestingly, we found that oral PPS also maintained its antihepcidin activity, even if its absorption was low, at about $6 \%$. While the low oral bioavailability of heparin and heparin LMW is 
E-ISSN: 2808-5361 http://e-journal.fkmumj.ac.id/
Proceeding The First

Muhammadiyah

Internasional- Public Health

and Medicine Conference

well known (Neves et al., 2016) in two patents it was reported that oral administration of LMW-oversulphate heparin induces an anticoagulant effect (EP0496233 (A1) -1992-07- 29-pharmaceutical composition for oral use containing low molecular weight heparin, its preparation and use Inventor Lattanzi Filippo, Sclavo petitioner; EP1792621 (A1) Orally administered heparin derivative Inventor Torri G.; Naggi A. Richiedente: Debiopharm SA). A possible explanation for the oral bioavailability of both LMWoversulfated heparin and PPS could be their ability to induce increased intestinal epithelial permeability. Such an interpretation agrees with the finding that oral administration of dextran sulfate, a highly negatively charged polysaccharides such as LMWoversulfated heparin and PPS, is associated with loss of occluded ZO-1 in the tight junction complex (TJ) [(Kim et al., 2020). Effects on hepcidin expression and iron distribution were seen with $300 \mathrm{mg} / \mathrm{kg}$ PPS in a single administration with a 50\% reduction in hepcidin mRNA. Thus, the use of oral PPS to suppress hepcidin seems feasible, offering a promising strategy to complement subcutaneous injection of PPS, especially in chronic treatment, but requires further study. For interstitial cystitis, the recommended oral treatment is $400 \mathrm{mg}$ of PPS daily for a long period (186 months) which is well tolerated (Kim et al., 2020), so it may be interesting, in the future, to try chronic treatment in mice with lower concentrations than those used in acute care. At present, subcutaneous PPS injection appears to be very effective in reducing hepcidin expression in terms of drug absorption, dose (much lower than oral administration), and negligible side effects. A recent study of H.M. Suranji Wijekoon and colleagues demonstrated that chronic subcutaneous treatment for 30 days with $20 \mathrm{mg} / \mathrm{kg} / \mathrm{day}$ PPS in rats with rheumatoid arthritis in the collagen-induced disease thritis model (CIA) showed promising anti-rheumatic effects with improved clinical outcomes and functional without side effects $(\mathrm{Hm}$, 2019), offers tit.

Chronic Disease or Inflammatory Anemia and in the form of genetic anemia called IRIDA; Pharmacological downregulation of hepcidin in this disorder may improve anemia. Commercial heparin is a potent inhibitor of hepcidin expression, by interfering with the BMP6/SMAD pathway. The non-anticoagulant heparin, modified to remove the anti-thrombin binding site, is equally potent and can be used to improve iron status. To perform its anti-hepcidin activity, heparin requires 2O- and 6O-sulfation average molecular weight (MW) of up to 4000-8000 Daltons, depending on the degree of sulfation. Pentosane polysulfate (PPS), which shares with high sulfate level heparin, is a compound with a low anti-coagulant activity that is already used for pharmaceutical treatment.

Interviewed nurses recognized that children with SCD used verbal or non-verbal communication and identified them crying and complaining as the most common manifestations. for younger children, methods for assessing pain are observation of facial expressions, irritation, and moaning; for older children: verbal reports and anxiety. 
E-ISSN: 2808-5361 http://e-journal.fkmumj.ac.id/
Proceeding The First

Muhammadiyah

Internasional- Public Health and Medicine Conference

Oral reports are the most widely used method when assessing a patient's illness. However, this is a method based on the individual's ability to communicate symptoms, so assessing the pain of children who do not speak is not yet more difficult (De Candido and Tacla, 2015)

Nurses recognize a child's pain and use pharmacological and non-pharmacological methods to control it but have difficulty assessing it. Based on a 13-week repeated dose toxicity study, $2.61 \mathrm{~g} / \mathrm{kg}$ and $22.03 \mathrm{~g} / \mathrm{kg}$ can be considered as NOAELs (no side effects were observed). effect level) in mice and monkeys, respectively. Most of the observations recorded at low and medium dose levels were typical of the pharmacological effects of EPO and were not uniquely associated with HM10760A toxicity. To elucidate the differences between human and animal physiology, the safety of HM10760A needs to be further confirmed in future clinical studies. Declaration of Competition of Interests The author declares that there is no conflict of interest.

The single-dose and repeated-dose toxicity profiles of HM10760A were characterized after single and repeated i.v. doses for a duration of up to 13 weeks in rats and monkeys. Although acute toxicity studies are not mandatory, we performed more sensitive sex (female) mice in small sizes to determine lethal dose before the main toxicity study (13 weeks). As a result, confirmation can be made of the expected pharmacological effect of HM10760A, namely an increase in erythropoiesis. In the main 13-week repeat toxicity study, treatment with HM10760A caused increased erythropoiesis in all testites of the treated group documented with increases in erythrocyte counts, Hb levels, HCT, and reticulocyte counts. Significant increase in absolute and relative spleen weight in moderate-dose males and both sexes in the high-dose group and spleen enlargement in high-dose males correlated with histological changes consisting of minimal to moderate extramedullary hematopoiesis. The increase in bilirubin levels noted in both sexes reflects increased turnover and degradation of erythrocytes. Changes in electrolyte levels could be an effect of decreased renal perfusion caused by high HCT values. Macroscopically, generalized reddish discoloration or single organ discoloration in some animals treated with moderate doses of HM10760A and most animals of both sexes treated with high doses of HM10760A was associated with congestion due to polycythemia and the associated increase in HCT values. Cardiac myocardial hypertrophy together with increased cardiac weight in animals treated with moderate and high doses of HM10760A was thought to be due to an increase in cardiac muscle workload. Some of the inflammatory and degenerative lesions noted were mainly associated with thrombosis or vascular lesions.

The latter may be a consequence of technically related lesions after repeated venipuncture. Elevated leukocyte and lymphocyte levels in mid-and high-dose women may be associated with these inflammatory lesions. and peritonitis), as well as in the kidney comprising an increased incidence and/or severity of tubular basophilia in animals treated with moderate and high doses of HM10760A 
in both sexes, which was still found in convalescent males and correlated with increased kidney weight. In addition, increased interstitial inflammation in men treated with high-dose HM10760A increased pyelitis in convalescent men, chronic necrosis, and/or infarction in men treated with highdose HM10760A, and single cases of peri-/arteritis were found. An increased incidence and/or severity of fat changes concomitant with centrilobular hypertrophy was noted in the livers of women treated with medium-dose HM10760A and in animals of both sexes treated with high-dose HM10760A, which is considered adaptive in the absence of further lesions, e. apoptosis, necrosis, fibrosis, etc. The increased incidence of reactive alveolar macrophages in the lungs of men treated with the combination of medium and high doses of HM10760A with a dose-related increase in lung weight cannot be ruled out with certainty to be a treatment effect. However, the low severity of these lesions is in the background, and hence, the significance of these lesions remains unclear. The primary test item-associated lesions due to the pharmacological action of the test item were noted in the spleen and bone marrow. They consisted of an increased incidence and/or severity of extramedullary hematopoiesis, particularly erythropoiesis in the spleen of women treated with moderate-dose HM10760A and animals of both sexes treated with high-dose HM10760A. The reason for the increase in granulopoiesis along with the M: E ratio to $70 \%$ : $30 \%$ may be a secondary consequence of the inflammatory lesion, and therefore reactive or due to the direct action of the test item. These changes were accompanied by bone marrow hypercellularity in animals of both sexes treated with high doses of HM10760A. In conclusion, the lesions are mainly related to the pharmacological action consisting of changes in the M: E ratio leading to an increase in the RBC count and HCT leading to hemodynamic changes. Inflammatory changes (thrombosis, inflammation, and necrosis) in some organs that even cause morbidity are secondary to excessive pharmacological action. EPO is known as a factor that regulates the production of red blood cells produced in the kidneys according to the concentration of oxygen in the body. Red blood cells are important blood cells for carrying oxygen into the body, and in patients with kidney failure, there is an abnormality in the secretion of EPO, which causes.

Iron is an important element that participates in many vital functions such as oxidative metabolism, an adequate erythropoietic function of cellular immune responses. Iron absorption must be carefully balanced to supply sufficient iron for the metabolism and to avoid the accumulation of excessive, toxic levels. Iron catalyzes the conversion of hydrogen peroxide to hydroxyl radicals by the Fenton/Haber-Weiss reaction cycle. Overproduction of free radicals as a consequence of cellular iron overload results in oxidative stress, a destructive process that leads to damage to cell structures, including lipids, proteins, and DNA. The body's iron level depends almost exclusively on its intestinal absorption since there I do not regulate the excretion pathway for these metal ions. Divalent metal 
transporter-1 (SLC11A2 / DMT1), also known as DCT1 and Nramp2, uses the H electrochemical gradient, $\mathrm{MN}$ as the driving force to transport divalent metal ions such as $\mathrm{Fe} 2+2+2+$, and other metals across the cell membrane. DMT1 I A 62-kDa protein that has 12 predictable spanning membrane domains with intracellular $\mathrm{N}$ and $\mathrm{C}$ termini and I are ubiquitously expressed, most notably in the proximal duodenum, in immature erythroid cells from the bone marrow, brain, and kidney [3]. Enterocytes take up dietary, unbound heme iron in the form of Fe, CD 2+ (ferrous iron) across the apical membrane via DMT1 [1]. This transporter is also involved in the transport of iron from the endocytic vesicle to the cytosol as part of the transferrin receptor (TfR)-mediated cellular uptake. Kinetic analysis has shown that DMT1 mediates the transport of Fe in an A-coupled manner with a stoichiometry of 1:1. DMT1 displays high affinity for $\mathrm{Fe} 2++$ and $\mathrm{H} 2++$ and $\mathrm{H}$ with apparent affinities of 1-5 mM and $1 \mathrm{mM}$, respectively [2]. The dysfunction of human T1DM is associated with iron deficiency anemia, iron overload disorders, neurodegenerative diseases (eg, Parkinson's and Alzheimer's disease), as well as cancers (colorectal and esophageal adenocarcinoma). The involvement of DMT1 in this disorder makes this protein a promising target for drug discovery. Specific modulators of DMT1 transport activity could be used as a tool to study the structure and transport mechanisms of this transporter as well as its role in iron homeostasis in health and disease. Over the past few years, significant efforts have been devoted to it. The discovery of the new DMT1 modulator. Emerging technologies such as genetic chemical screening have led to the discovery of small molecule compounds that differentiate between non-transferrin-bound iron uptake and transferrin-mediated iron uptake. Two small molecules of the compound were reported to specifically block DMT1-mediated iron uptake. More recently, a series of benzylisothiourea and pyrazole derivative compounds were shown to act as potent DMT1 inhibitors. However, there is scarce information available about the mechanism of action of this small molecule compound in DMT1 transporting activity. In the present study, we extended the search for new small-molecule compounds that specifically block human DMT1-mediated iron uptake. We found a new compound, pyrimidine 8, which mediates a reversible linear noncompetitive inhibition of hDMT1 transport activity. This compound did not affect hDMT1 cell surface expression and showed no dependence on its extracellular $\mathrm{pH}$. To our knowledge, this is the first experimental evidence that DMT1 can be allosterically regulated by pharmacological agents. (Wegmüller et al., 2020).

Showing that the noncompetitive inhibition of hDMT1-mediated Fe transport by pyrimidine 8 did not exhibit any dependence on extracellular $\mathrm{pH}$ at the $\mathrm{pH}$ values measured. In summary, we found that the pyrimidine compound 8 mediates a linear noncompetitive inhibition of hDMT1-mediated $\mathrm{Fe} 2+2+$ transport activity. This inhibition was reversible, did not affect the cell surface expression of the transporter, and showed no dependence on extracellular $\mathrm{pH}$. It's the discovery of pyrimidine 
The relationship between patent ductus arteriosus (PDA) and neonatal morbidity, mortality, and poor neurodevelopmental outcomes in later life has been the focus of heated debate for decades. Despite numerous observational studies and more than 50 randomized controlled trials (RCTs), agreed agreement on its management in the preterm neonatal population remains elusive. Controversy persists regarding the determination (and definition) of significant ductal hemodynamics, identification of the appropriate infant for therapy, selection of treatment regimens, and the exact impact of PDA treatment on meaningful short- and long-term outcomes. The ongoing substantial heterogeneity in clinical practice regarding PDA management was recently highlighted by the European Population-Based Cohort Study (EPICE) which reported that PDA treatment varied from $10 \%$ to $39 \%$ between regions, and this difference could not be explained by differences in perinatal characteristics. . There is increasing consensus that shunt volume, rather than periodic estimates of transductal diameter, represents a more holistic and accurate measurement of the hemodynamic impact of PDA. The physiology of channel impact is governed by Poiseuille's law which states that "At constant driving pressure the rate of fluid flow through a tube is directly proportional to the fourth power of the tube radius and inversely proportional to the length and viscosity of the tube. Poiseuille's law asserts that the diameter of the vessel plays the largest role of all factors in determining the rate of blood flow of the vessel because the rate of blood flow through the vessel is directly proportional to the fourth power of the radius of that vessel. In the setting of a PDA, the length of the vessel, the pressure gradient across the whole vessel, blood viscosity, and vessel diameter all change constantly during the first few days after birth. The dynamic nature of the components that regulate flow makes estimating shunt volume difficult at best (Smith, McNamara, and EL-Khuffash, 2018)

Management of premature neonates with PDA remains contentious. The justification for a conservative approach to PDA management arises from the large body of evidence that no benefit of ductal closure has been found in studies of prophylactic treatment. The conservative approach recommends active management of the PDA shunt, without the administration of drugs that promote PDA closure, and includes fluid restriction, avoidance of anemia, ventilation strategies, and diuretic therapy. It is important to clarify that the conservative approach should not be construed as "avoidance" of any PDA assessment, monitoring, or management. It is also important to recognize that a strategy that is a conservative approach does not have a strong evidence base in the population of interest, may have potentially harmful side effects, and may expose infants with high volume shunts to significant consequences of ductal patency. The ideal approach to PDA management remains unclear; widely used strategies include universal or targeted prophylaxis, medical and surgical strategies to close a PDA that may be early or late, and finally a conservative approach to a PDA shunt. Trials are ongoing progress to investigate the impact of a conservative approach and 
E-ISSN: $2808-5361$ http://e-journal.fkmumj.ac.id/
Proceeding The First

Muhammadiyah

Internasional- Public Health

and Medicine Conference

investigate the effect of initial targeted therapy based on the PDA risk score. In the meantime, clinicians should use the best available evidence to guide treatment approaches. A comprehensive assessment of the PDA shunt volume can help define the patient with the greatest physiologic disturbances secondary to the volume shunt. This strategy should limit the use of medication, which is potentially harmful, to infants where the benefits outweigh any risks. Thus, a risk-based approach to patient selection for PDA treatment is an emerging area of interest that requires further study.

\section{CONCLUSION AND SUGGESTIONS}

Based on the results of the research from the 6 articles stated that patients with anemia were given non-pharmacological therapeutic interventions, namely:

1. Nursing Delirium Screening Scale (Nu-DESC) twice daily for the first 3 days after surgery. Further outcome variables were somatic laboratory parameters and variables related to surgery, anesthesia, and postoperative recovery.

2. Regulating the expression of hepcidin, Chronic Disease, or Inflammatory Anemia and in the form of genetic anemia called IRIDA; Pharmacological downregulation of hepcidin in this disorder may improve anemia. Commercial heparin is a potent inhibitor of hepcidin expression, by interfering with the BMP6/SMAD pathway. The non-anticoagulant heparin, modified to remove the anti-thrombin binding site, is equally potent and can be used to improve iron status.

3. Identification of pain (emotional support and promotion of comfort), Nurses recognize the child's pain and use pharmacological and non-pharmacological methods to control it but have difficulty assessing it.

4. Treatment with HM10760A causes increased erythropoiesis,

5. Divalent Metal transporter1 (DMT1) mediates iron absorption through the intestinal mucosa and facilitates peripheral delivery of iron released by transferrin diendosome,

6. A comprehensive assessment of the PDA shunt volume can help delineate the patients with the greatest physiologic disturbances secondary to the volume shunt. This strategy should limit the use of medication, which is potentially harmful, to infants where the benefits outweigh any risks

\section{REFERENCE}

W. (2017) Nutritional Anaemias : Tools for Effective Prevention, Who.

A Vriori Reysca Avista, Prabowo, A. and Hafiduddin, M. (2019) 'Upaya Meningkatkan Keefektifan Manajemen Kesehatan Dengan Pemberian Jus Jambu Biji Merah Pada Keluarga Dengan Anemia', pp. 1-145. Available at: http://repository.itspku.ac.id/id/e print/54. 
Alleyne, M., Horne, M. K. and Miller, J. L. (2008) 'Individualized Treatment for Iron-deficiency Anemia in Adults', American Journal of Medicine, 121(11), pp. 943-948. DOI: 10.1016/j.amjmed.2008.07.012.

Benitz, W. E. (2011) 'Learning to live with patency of the ductus arteriosus in preterm infants', Journal of Perinatology. Nature Publishing Group, 31, pp. S42-S48. DOI: 10.1038/jp.2010.175.

Bohlius, J. et al. (2006) 'Cancer-related anemia and recombinant human erythropoietin - An updated overview', Nature Clinical Practice Oncology, 3(3), pp. 152-164. DOI: 10.1038/ncponc0451.

BRASIL. (2015) Doença Falciforme: Diretrizes Básicas da Linha de Cuidado., Brazilia, DF.

Brasil and Ministério da Saúde (2012) Condutas básicas para tratamento.

Brissot, P. et al. (2018) 'Haemochromatosis', Nature Reviews Disease Primers, 4. doi: 10.1038/nrdp.2018.16.

Brito, A. et al. (2015) 'Folate and Vitamin B12 Status in Latin America and the Caribbean: An Update', Food and nutrition bulletin, 36(Supplement 2), pp. S109-S118. DOI: $10.1177 / 0379572115585772$.

Campelo, L. M. N. et al. (2018) 'The pain of children with sickle cell disease: the nursing approach', Revista Brasileira de enfermagem, 71(suppl 3), pp. 1381-1387. DOI: 10.1590/0034-71672016-0648.

De Candido, L. K. and Tacla, M. T. G. M. (2015) 'Avaliação e caracterização da dor na criança: Utilização de indicadores de qualidade', Revista Enfermagem, 23(4), pp. 526-532. doi: 10.12957/reuerj.2015.10514.

D’Adamo, C. R. et al. (2018) 'A Food-Derived Dietary Supplement Containing a Low Dose of Iron Improved Markers of Iron Status Among Nonanemic Iron-Deficient Women', Journal of the American College of Nutrition. Taylor \& Francis, 37(4), pp. 342-349. DOI: 10.1080/07315724.2018.1427158.

De-Regil, L. M. et al. (2015) 'Effects and safety of periconceptional oral folate supplementation for preventing birth defects, Cochrane Database of Systematic Reviews, 2015(12). DOI: 10.1002/14651858.CD007950.pub3.

EDA and ADS (2014) 'The DSM-5 criteria, level of arousal and delirium diagnosis: inclusiveness is safer (European Delirium Association and American Delirium Society)', BMC Medicine, 12(1), p. 141. Available at: http://bmcmedicine.biomedcentral.com/articles/10.1186/s12916014-0141-2.

George, C. et al. (2018) 'Haematological profile of chronic kidney disease in a mixed-ancestry South African population: A cross-sectional study, BMJ Open, 8(11). DOI: 10.1136/bmjopen-2018- 
025694.

Gerardin, M. et al. (2021) 'Descriptive analysis of sickle cell patients living in France: The PHEDRE cross-sectional study', PLoS ONE, 16(3 March), pp. 1-17. DOI: 10.1371/journal.pone.0248649.

Ginzburg, Y. Z. (2019) 'Hepcidin-ferroportin axis in health and disease', Vitamins and Hormones, 110, pp. 17-45. DOI: 10.1016/bs.vh.2019.01.002.

Guillem, F. et al. (2012) 'Inactive matriptase-2 mutants found in IRIDA patients still repress hepcidin in a transfection assay despite having lost their serine protease activity, Human Mutation, 33(9), pp. 1388-1396. DOI: 10.1002/humu.22116.

Helmyati, S. et al. (2018) 'No Difference Between Iron Supplementation Only and Iron Supplementation with Synbiotic Fermented Milk on Iron Status, Growth, and Gut Microbiota Profile in Elementary School Children with Iron Deficiency', Current Nutrition \& Food Science, 16(2), pp. 220-227. DOI: 10.2174/1573401314666181017110706.

Hm, S. W. (2019) 'Therapeutic Prospective of Stem Cells in Veterinary Practice', pp. 1-5. DOI: 10.23880/oajvsr-16000179.

Izaks, G. J., Westendorp, R. G. J. and Knook, D. L. (1999) 'The definition of anemia in older persons', Journal of the American Medical Association, 281(18), pp. 1714-1717. DOI: 10.1001/jama.281.18.1714.

Jelkmann, W. and Hellwig-bürgel, T. (2001) 'Chapter 12 Biology of erythropoietin’, pp. 169-170.

Kim, H. Y. et al. (2020) 'Rumex japonicus Houtt. alleviates dextran sulfate sodium-induced colitis by protecting tight junctions in mice', Integrative Medicine Research. Korea Institute of Oriental Medicine, 9(2), p. 100398. DOI: 10.1016/j.imr.2020.02.006.

Kumar, A. et al. (2020) 'Surveillance based estimation of the burden of malaria in India, 2015-2016', Malaria Journal. BioMed Central, 19(1), pp. 1-12. DOI: 10.1186/s12936-020-03223-7.

Lim, H.-K. et al. (2020) 'Single-and repeat-dose toxicity of HM10760A, a long-acting erythropoietin, in rats and monkeys', Toxicology and Applied Pharmacology, 402, p. 115126. DOI: https://doi.org/10.1016/j.taap.2020.115126.

Llor, J. (2014) 'Prise en charge de la douleur de l'enfant', Revue Medicale Suisse, 10(415), pp. 267270. doi: 10.1016/b978-2-294-70633-2.50435-2.

Mahmood, I. (2020) 'Prediction of Clearance of Monoclonal and Polyclonal Antibodies and NonAntibody Proteins in Children: Application of Allometric Scaling', Antibodies, 9(3), p. 40. DOI: $10.3390 /$ antib9030040.

Neves, A. R. et al. (2016) 'Strategies to overcome heparins' low oral bioavailability, Pharmaceuticals, 9(3), pp. 1-16. DOI: 10.3390/ph9030037. 
E-ISSN: 2808-5361 http://e-journal.fkmumj.ac.id/
Proceeding The First

Muhammadiyah

Internasional- Public Health

and Medicine Conference

Park, C. H. et al. (2001) 'Hepcidin, a Urinary Antimicrobial Peptide Synthesized in the Liver', Journal of Biological Chemistry, 276(11), pp. 7806-7810. DOI: 10.1074/jbc.M008922200.

Poli, M. et al. (2014) 'Hepcidin antagonists for potential treatments of disorders with hepcidin excess', Frontiers in Pharmacology, 5 APR(April). DOI: 10.3389/fphar.2014.00086.

Poli, M. et al. (2017) 'Non-anticoagulant heparins are hepcidin antagonists for the treatment of anemia', Molecules, 22(4), pp. 1-9. DOI: 10.3390/molecules22040598.

Resmi, D. C. and Fibrinika Tuta Setiani (2020) 'Literatur Review: Penerapan Terapi Non Farmakologis Terhadap Peningkatan Kadar Hemoglobin Pada Remaja Putri Dengan Anemia', Jurnal Ilmiah Kesehatan, pp. 44-52.

Roth, M. P., Meynard, D. and Coppin, H. (2019) 'Regulators of hepcidin expression, Vitamins and Hormones, 110, pp. 101-129. DOI: 10.1016/bs.vh.2019.01.005.

Schmidt, P. J. (2015) 'Regulation of iron metabolism by hepcidin under conditions of inflammation, Journal of Biological Chemistry. Â@ 2015 ASBMB. Currently published by Elsevier Inc; originally published by American Society for Biochemistry and Molecular Biology., 290(31), pp. 18975-18983. DOI: 10.1074/jbc.R115.650150.

Smith, A., McNamara, P. J. and EL-Khuffash, A. F. (2018) 'Non-pharmacological management of a hemodynamically significant patent ductus arteriosus', Seminars in Fetal and Neonatal Medicine, 23(4), pp. 245-249. DOI: 10.1016/j.siny.2018.03.008.

Solehati, T., Sriati, A. and Kosasih, C. E. (2020) 'Intervention To Reduce Post-Partum Depression', Jurnal Keperawatan Jiwa, 8(2).

Tam, E. et al. (2020) 'Micronutrient Supplementation and Fortification among Children Under-Five in Low- and', Nutrients, 12(289), pp. 1-30.

Valent, P. et al. (2018) 'Normal and pathological erythropoiesis in adults: From gene regulation to targeted treatment concepts', Haematologica, 103(10), pp. 1593-1603. DOI: 10.3324/haematol.2018.192518.

Wang, C. et al. (2017) 'Reciprocal regulation between hepcidin and erythropoiesis and its therapeutic application in erythroid disorders', Experimental Hematology. ISEH - International Society for Experimental Hematology, 52, pp. 24-31. DOI: 10.1016/j.exphem.2017.05.002.

Wegmüller, R. et al. (2020) 'Anemia, micronutrient deficiencies, malaria, hemoglobinopathies and malnutrition in young children and non-pregnant women in Ghana: Findings from a national survey', PLoS ONE, 15(1), pp. 1-19. DOI: 10.1371/journal.pone.0228258.

WHO (2012) 'Anaemia Policy Brief', (6), pp. 1-7. Available at: http://www.who.int//iris/bitstream/10665/148556/1/WHO_NMH_NHD_14.4_eng.pdf.

Who and Chan, M. (2011) 'Haemoglobin concentrations for the diagnosis of anemia and assessment 
E-ISSN: 2808-5361 http://e-journal.fkmumj.ac.id/
Proceeding The First

Muhammadiyah

Internasional- Public Health

and Medicine Conference

of severity, Geneva, Switzerland: World Health Organization, pp. 1-6. DOI: 2011.

Zhai, W. et al. (2016) 'Changes in postoperative cognitive function during off-pump coronary artery bypass graft surgery: Dose-response of propofol', International Journal of Clinical and Experimental Medicine, 9(6), pp. 10939-10946.

Zhu, Z. et al. (2021) 'Anemia and associated factors among adolescent girls and boys at 10-14 years in rural western China', BMC Public Health, 21(1), pp. 1-14. DOI: 10.1186/s12889-02110268-z. 
Volume I Tahun 2021 November 2021
E-ISSN: 2808-5361

http://e-journal.fkmumj.ac.id/
Proceeding The First

Muhammadiyah

Internasional- Public Health

and Medicine Conference 